\title{
Afrikaners in post-apartheid South Africa: Inward migration and enclave nationalism
}

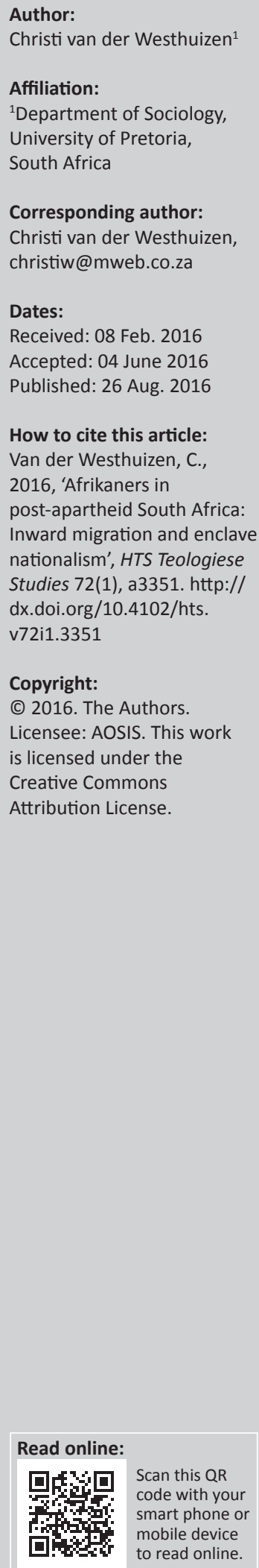

South Africa's transition to democracy coincided and interlinked with massive global shifts, including the fall of communism and the rise of western capitalist triumphalism. Late capitalism operates through paradoxical global-local dynamics, both universalising identities and expanding local particularities. The erstwhile hegemonic identity of apartheid, 'the Afrikaner', was a product of Afrikaner nationalism. Like other identities, it was spatially organised, with Afrikaner nationalism projecting its imagined community ('the volk') onto a national territory ('white South Africa'). The study traces the neo-nationalist spatial permutations of 'the Afrikaner', following Massey's (2005) understanding of space as (1) political, (2) produced through interrelations ranging from the global to micro intimacies, (3) potentially a sphere for heterogeneous co-existence, and (4) continuously created. Research is presented that shows a neo-nationalist revival of ethnic privileges in a defensive version of Hall's 'return to the local' (1997a). Although Afrikaner nationalism's territorial claims to a nation state were defeated, neo-nationalist remnants reclaim a purchase on white Afrikaans identities, albeit in shrunken territories. This phenomenon is, here, called Afrikaner enclave nationalism. Drawing on a global revamping of race as a category of social subjugation, a strategy is deployed that is here called 'inward migration'. These dynamics produce a privatised micro-apartheid in sites ranging from homes, to commercial and religious enterprises, to suburbs. Virtual white spaces in the form of Afrikaans media products serve as extensions of these whitened locales. The lynchpin holding it all together is the heteronormative, middle-class family, with consumption the primary mode of the generation of its white comfort zones.

\section{The neo-nationalist form of post-apartheid Afrikaner politics}

South Africa's transition to democracy coincided and interlinked with massive global shifts. The fall of the Soviet Union and the end of the Cold War sparked the rise of western capitalist triumphalism (Terreblanche 2012). Late capitalism operates through paradoxical global-local dynamics: in its processes of commodification, late capitalism both universalises identities and expands local particularities (Hall 1997a, 1997b). In this postmodern condition, time-space is reconfigured and anchorages become dislocated (Rattansi 1994). Populations are more mobile including South Africans - as the country is re-inducted into global circuits. Apartheid's geographical divisions prove to be enduring, but they are resisted. South Africans do not only have to contend with making sense of their dislocated identities after the collapse of apartheid certainties, but also find they are navigating a global flux in identities.

This article examines the erstwhile hegemonic identity of apartheid, 'the Afrikaner'. From the above observations, it is clear that identity is spatially organised (Hall 1997b:43). Moreover, space is political (Massey 2005). In South Africa, apartheid power relations are manifested in racial geographies. 'The Afrikaner' was a product of Afrikaner nationalism that projected its imagined community ('the volk', in this instance) onto a vaunted nation state as territory. The object of the National Party's version of Afrikaner nationalism, after achieving state power in 1948, was for 'White South Africa', to be spatially crafted by segregating people on the basis of race. Apartheid, as white minority rule, served as an operationalisation of Afrikaner nationalism. With the collapse of minority rule and the loss of the nation state, turmoil besets the Afrikaner identity. What are the post-nation state permutations of this identity, including spatially? In refuting that nationalism requires the nation state as a necessary object, Kriel (2012:428) insists that nationalism can also have 'lower-order forms of power' as its objective. The core drive of nationalism can amount to having the nation 'collectively and freely institutionally expressed' (O'Leary in Kriel 2006:57).

Note: This article draws in part on research for the author's Ph.D. thesis, titled 'Identities at the intersection of race, gender, sexuality and class in a liberalising, democratising South Africa: The reconstitution of 'the Afrikaner woman' (University of Cape Town, 2013). 
This would fit with a casting of nationalisms without states as focused on cultural, economic, and social autonomy, while accepting the political framework of the state where such nationalisms occur (McCrone 1998:126). Apart from institutional expression, nationalism without a state may be channelled through symbolic articulations to preserve a cultural community (Kriel 2006:61). Kriel (2006) cautions, in a convincing argument, that cultural nationalism is no less political because it is cultural. According to McCrone (1998:128), one of the hallmarks of neo-nationalisms nationalisms without states - is a 'complex relationship between cultural and political nationalism'. Neo-nationalisms are characterised by an ambiguity about aims, specifically about whether self-determination is sought (p. 129). This ambiguity is true of post-apartheid Afrikaner politics, where the Afrikaner 'rights' movement, Solidarity, hints at selfdetermination as a political goal but instead opts to use the constitutional regime, while protecting existing ethno-racial institutions or building new ones. Territorial projects such as Orania and Kleinfontein have failed to attract the majority of white Afrikaans-speaking South Africans (van Wyk \& Sharp 2016).

While agreeing that a preponderance of white Afrikaansspeakers has abandoned their Afrikaner nation state ambitions, this study traces whether other remnants of Afrikaner nationalism's spatial aims remain. The postapartheid politics of Afrikaner identity is though to adopt a neo-nationalist form, which satisfies McCrone's point of departure that neo-nationalism may be analogous to mainstream nationalism but possesses a distinctly different character and place in history (p. 128). The loss of the nation state has literally cut down to size the Afrikaner identity's primary ideological vehicle and relegated it to the minority nationalism that it is (Keating \& McGarry 2001). Moving from the position that nationalism does not necessarily have the nation state as its aim, but that it involves a quest for cultural, social, and economic autonomy, including institutional and cultural expression, a number of questions can be asked.

1. Has the formerly hegemonic identity of apartheid abandoned whiteness as spatial mode of exclusion?

2. How does race interact with other social categories, such as gender, class, and sexuality, in white, Afrikaansspeaking people's creation of post-apartheid spaces?

3. If nationalism includes the desire for free institutional expression, what does this mean for the family?

In answering these questions, this article is structured as follows. First, Afrikaner identity is placed in relation to other South African identities. Its post-apartheid embattlement occurs in the context of two contemporary global-local strategies for identification that either work with either the retrogressive elements of the 'global postmodern' or the defensive mode of 'the return to the local' to elaborate entitlements. Research is discussed that shows how Afrikaner nationalist fragments are drawn together to reclaim ethnic privileges, using the neo-nationalist strategy of what is here called 'inward migration'. Inward migration is a wielding of ethnicity (Afrikanerhood) to withdraw from shared national spaces while whitening 'own spaces' (Blaser \& van der Westhuizen 2012:386). The article shows how, 22 years into democracy, an Afrikaner neo-nationalism has arisen that shifts the perspective from the nation state to smaller locales, targeted to be made 'homely' again. This phenomenon is called Afrikaner enclave nationalism. Therefore, in addition to Kriel's identification of institutional and symbolic expressions as vehicles for a post-apartheid Afrikaner nationalism, this study finds a remaining territorial dimension, albeit at a much reduced scale when compared to the erstwhile Afrikaner nationalist creation of a white nation state. The theoretical framing of the study is sketched in the next section, followed by research that substantiates the above assertions.

\section{Afrikaner identity and postmodern global-local dynamics}

'The Afrikaner' could, in the widest sense, be understood as an identity flavouring race, gender, class, and sexual elements with a particularism drawn from an ever-pliable and politically potent category of ethnicity. 'The Afrikaner' was forged in the first half of the twentieth century in co-constitutive relations with, on the one hand, indigenous black people and, on the other, white British colonialists. At the time, the identity was a reaction to the threshold condition of 'poor whites', regarded as in imminent 'danger' of 'deteriorating' to 'the station and class' of 'the coloured' (Adhikari 2005:11, 14, 15; Du Toit 2003:172; Erasmus 2005:17-18). It was an aspirational identity seeking to rid itself from the stigma of deteriorated whiteness. It aimed to accomplish equality with hegemonic global whiteness, as represented by British colonialists and later white English-speaking South Africans (WESSAs) (Steyn 2003). Afrikanerhood's nascent stirrings (Bradford 2000; Du Toit 2003; Vincent 1999, 2000) coincided with the invention of ethnicity as a social category, circa 1900 (Hattam 2001). Ethnicity, compared to other categories, is without an essence or original feature but is fabricated as a 'natural community' in the past or future, with boundaries continuously being (re) drawn (Hall 2001; Rattansi 1994:53; Smith 1998:204). It is produced through the competing and complementary routes of race and language which, articulated together, invoke the nation as a self-determined unit (Balibar 1991:96; Hofmeyr 1987). Ethnicity overlaps with and operates according to a similar logic as that of race, making it impossible to contain these categorisations in relation to each other (Rattansi 1994:53).

After South Africa's democratic transition, with the apartheid imaginary in tatters, whiteness, particularly its Afrikaner permutation, is delegitimised, as 'Afrikaners cannot escape the fact that the system was put in place in their name' (Steyn 2003:222, emphasis in original). Afrikaner nationalism is a discourse in disarray, catapulting 'the Afrikaner' into states of confusion and defence (Steyn 2003, 2004; van der Westhuizen 2007; Verwey \& Quayle 2012; Vestergaard 2001). 
The identity's implication in apartheid, instrumental in the political, economic, and social ascendancy of Afrikaners, re-stigmatises it as morally suspect.

For subjects of embattled Afrikaner identity, being white remains more important than ethnicity - a position similar to that of 'white ethnics' in the US (Dyer 2005:12; Roediger 2002). Complex reworkings of ethnicity and race reinvent racism, which has proven remarkably durable. For modern subjects, racism works as a key mode of making sense about themselves and their worlds, and for producing these worlds (Goldberg 1993:9). New Right discourses challenge antiracist mobilisation by conjuring 'primordial notions of ethnic exclusivity' (Goldberg \& Solomos 2002:8). Racism is renewed by a shift from biological to cultural justifications (Balibar 1991; Essed 2002; Gilroy 2007; Rattansi \& Westwood 1994). Ethnicity figures again, operationalised as a cultural marker (Rattansi 1994) through 'cultural socialisation' (Goldberg 2002:247). The goal of racial supremacy based on social hierarchy is replaced with cultural homogeneity, elaborated through tradition, while structural inequalities are covered with racist denials (Goldberg \& Solomos 2002). In South Africa, even 'hybridising' post-apartheid South African whiteness (which included Afrikaans whiteness) devises rehabilitative strategies to reinforce its grip on ethnic entitlements (Steyn 2003, 2004).

The fall of official apartheid re-inducted South Africa into global circuits of meaning, at a time of seismic upheavals in identities. Cultural theorist Stuart Hall (1997a:25) warns that the decline of the nation-state is a 'dangerous moment' as feeling beleaguered gives rise to narrow and defensive exclusivist national identities. He describes these vast changes compellingly. The hold of 'great collective social identities' over individuals slips, along with their impression of homogeneity (Hall 1997b:44-45). Worldwide struggles for voice bring 'new subjects, new genders, new ethnicities, new regions, new communities' to the fore (Hall 1997a:34). With the apartheid imaginary faltering, South Africans joined the fray.

Hall (1997a:22) contends that this conjuncture involves the disruption of the projection of a national cultural identity as standing for a national formation. The 'nation' cloaks a 'subset of identifications' that relates to other identities, also within the nation (Peterson 2000:55). Afrikaner nationalism was operationalised by apartheid, which had been hegemonic in providing individuals with the material of meaning making, drawing on ever-adapted race, gender, and other categories (Norval 1996). As the centre weakens, so the differences pull away (Hall 1997a:37). In the wake of the collapse of apartheid certainties, new loacales arise in a proliferation of identities. The shift is away from singular entities of power to decentralised social and economic organisation. Hall notes that shifts are met with countershifts. What are the moves aimed at stemming the fragmentation of apartheid identities?

Globally, instead of the disappearance of nationalist sentiment, the state system has been racked by transnational pressures from above and insistent cultural and territorial identities from below (Keating \& McGarry 2001). Hall (1997a) coins the term 'the global postmodern' to encapsulate two contradictory moments. The first is the over-concentrated capitalist economic power that paradoxically works as a homogenising force, while also living through cultural particularism and pleasure as consumption. The second is the enclosed, defensive national cultural identity, which is nostalgic about nationalism (pp. 32-33). In contrast to the global postmodern, 'a return to the local' is a finding of languages about the past and hidden histories, local roots that are knowable against the standardising of the global postmodern and its 'flux of diversity' (p. 35). This reaching for grounding involves a rediscovery of ethnicity. Similar to the global postmodern, it is a contradictory terrain, and it can adopt an outward or inward-moving posture. Outward postures remember the positioning of the particular within a discourse to avoid mistaking itself for a universal identity, and to think ethnicity as a continuous process, filled with contradictions. In contrast, inward postures can usher in a withdrawal into self-protective, exclusivist enclaves, resisting modernity in a turn towards fundamentalism. Similar to Hall's argument, Geschiere and Meyer (1998) suggest that greater flows are met with greater efforts at fixing. Culturally homogenising globalisation provokes culturally heterogenising localisms (Geschiere \& Meyer 1998). Global reconfigurations render locality more uncertain, provoking 'determined efforts towards boundary-making and closure, expressed in terms of belonging and exclusion' - processes termed 'autochthony' (Geschiere \& Nyamnjoh 2000:425). The 'autochthonic dream' is of a "'pure" otherless universe' (Yuval-Davis 2011:para 1).

Against this background, this study applies Massey's (2005:9) description of space to explore Afrikaner neo-nationalist manifestations. She describes space, first, as produced through interrelations ranging from the global to the 'intimately tiny'; second, as a potential sphere for 'co-existing heterogeneity'; and, third, as 'always in the process of being made' (p. 9). Are we seeing an autochthonous 'return to the local', or an embrace of greater heterogeneity and fluidity, or a nostalgic reaching for nationalism, and how are the contradictory effects of simultaneously heterogenising and homogenising global capitalism navigated? The next section briefly outlines the methodology of this study.

\section{Methodology}

In this study, identities are analysed as constructed in particular historical and institutional sites, produced by subjects (individuals) through discursive formations and practices by 'specific enunciative strategies' and within 'the play of specific modalities of power' (Hall 1996:17). The excerpts from magazine texts and interviews in this chapter surface discourses that undergird these strategies. Drawing on discourse theory (Carpentier \& de Cleen 2007; Laclau \& Mouffe 1990), a discourse analysis probing for patterns of meaning making was conducted of texts from a popular women's magazine and texts generated in focus group and 
individual in-depth interviews. Purposive sampling was used to find respondents who self-identified as Afrikaansspeaking, white, middle-class, heterosexual women, a group about which little research exists, in either the apartheid or post-apartheid eras. The decision to target both Johannesburg and Cape Town was based on the socio-political contrast between the cities, as comparative research found an emphasis on 'shared lifestyles' in Johannesburg, in contradiction to cultural and class compartmentalisation in Cape Town, where demands for cultural homogeneity at the neighbourhood level extended to the level of the city and the country (Bekker \& Leildé 2006:155-158). The interviews took place in Johannesburg and the northern suburbs of Cape Town in 2011 and 2012 with respondents between the ages of 30 and 65 . The aim with the discourse analysis was to deconstruct normative assumptions of the master categories of inequality, such as race and gender, and investigate the possibilities for 'a politics that is at once more complex and inclusive' (McCall 2005:1777).

As per Massey's observation of the production of space as a continuous process, that also occurs at the level of interpersonal intimacies, the study sought to detect micro-level, taken-for-granted constructions. This approach is fruitful when studying race and racism, as the apartheid state relied on 'commonsense' understandings of race to deploy apartheid in everyday situations (Posel 2001). Goldberg (2002:245) traces the 'routinisation of race' in racial states as suffusing the ordinary and invisibilising race. Anti-racist resistance and human rights discourses are challenged by the denial of race and the discrediting of discontent over racism, imbricated in commonsense discourses (Essed 1991, 2002). This focus on the everyday resonates with Billig's (1995) notion of 'banal nationalism' produced through ordinary and repetitive practices. The next section analyses the discourses gleaned from the research interviews.

\section{'Inward migration': Ethnicity and culture as Trojan horses for racism}

The study finds whitening to be the form that the constant making of Afrikaans spaces takes in some metropolitan areas. These areas are situated at a distance from the main urban centres but with a sufficient concentration of infrastructure and capital to be secondary nodes of the large cities of Cape Town and Tshwane (Pretoria). Durbanville is an upper middle class area in the predominantly Afrikaans northern suburbs behind Cape Town's boereworsgordyn - a term meaning literally the 'curtain' of a sausage associated with Afrikaners, used by Capetonians to refer to the geographical language and racial divide in the city. ${ }^{1}$ The other white enclave that emerges in the study is similarly positioned in the suburban sprawl between the metropolitan centres of

1.The prevalence of the term is exemplified by a December 2012 commercial holiday supplement to the English language Cape Town newspapers featuring a page follows: 'The northern suburbs are subtly separated from follows: "The norther suburbs are subtly separated from Cape Town's southern suburbs by what locals call "the boerewors curtain", an imaginary line that English-spe the predominantly Afrikaans-speaking northern suburbs from the English-speakng southern suburbs, although with the increasingly multicultura nature of suburban Cape Town this is a generalisation' (Welcome to the Cape Summer Edition 2012). Note the use of 'multicultural' as code for race.
Johannesburg and Tshwane: Centurion is a middle class to affluent urban area which enjoyed independent municipal status during apartheid but has subsequently been incorporated into the greater Tshwane, which includes the country's capital Pretoria. Colloquially, it is also referred to as 'behind the boereworsgordyn'.

The potential for spaces crafted from heterogeneous coexistence, as suggested by Massey, is thwarted by the operation of race under the guise of culture, as emerges in the following text. This test was generated in an interview with a subject identified as dissident due to her critical stance on the dominant form of Afrikaner identity. In this narrative, subjects' initial opprobrium about English-speakers in an Afrikaans space drops away and is replaced with 'warmth'. The allowances made in respect of ethnicity (deviating from the rule of 'speaking Afrikaans') do not apply to race, however.

Katrien $^{2}$ (42): In the Durbanville area, there is a certain ... closure. Our people, our language, our tradition, our way of doing ... In the restaurant [where I work], there are two or three English [speaking] waiters. Afrikaans people's first comment will be 'but, oh, it's an English waiter'. It takes them 20 minutes to get used to the English waiter ... [only] then [do] they become spontaneous and warm ...

Researcher: And if you were to appoint a black waiter?

Katrien: Everybody knows it won't work in this specific area ...

Researcher: Is there a specific decision not to appoint black people?

Katrien: It's never been said black on white [in writing] but it's pretty much the story behind the story, which is ridiculous to me. You get black people nowadays who speak such good Afrikaans.

Researcher: Coloured people speak Afrikaans.

Katrien: Exactly. It is interesting how there are still contexts that get stuck.

Researcher: Let's say, hypothetically, you appointed a black person or a coloured person. What kind of reaction do you expect?

Katrien: [Among the waiters], we have a little Indian guy who sometimes wears a beanie ... If he does one thing wrong, it's immediately, 'this guy doesn't know what he's doing, he's acting like a clown ... what's that beanie on his head?'... But there's another waiter with tatoos whose hair hangs in his eyes, but there are never complaints about his appearance ... [The beanie] is neat and clean, you know'.

Apposite to the analysis here is Harris's (1995:281, 283) observations on whiteness as a 'proposition imposed through subordination' and as an identity marker that is not 'inherently unifying' but constituted through the exclusion from privileges of those deemed 'not white'. The narrative reveals the adjustability of the parameters of the ethnic whiteness being discussed here. The first is to admit Englishspeaking whites. The second is to allow aesthetically nonconforming white bodies. Race overrides ethnicity as a determinant of the terms of access to Afrikaans 'warmth', as 2.Pseudonym. All interviews are own translations from Afrikaans. 
English-speaking whites are (eventually) allowed in. The 'waiter with tatoos' is white, but the respondent omits race in describing him, confirming whiteness as the unmarked normative position in this context. The borders of the ethnic whiteness under discussion have been enlarged to include previously unacceptable white bodies, such as tatooed ones (Bell \& Valentine 1995).

The same allowances are not made for blackness, as exclusivity enhances the value of whiteness. White supremacy is reproduced though social interactions with black others degraded as socially inferior (p. 283), confirmed by the respondent's use of the dimunitive to describe the Indian waiter in the story. Whiteness means empowerment to pronounce on black others. The messaging marking black bodies flows among 'whites' (white clients to white waiters to white proprietors). This is a signature manoeuvre in which white inclusion is effected through the incorporation of unmarked white bodies implicitly positioned as 'neat and clean'. The respondent's emphasis on the 'beanie' woollen cap being 'neat and clean' suggests that this is an 'exception' from a rule that rests on a racialised and classed binary. Similarly, the references question the Indian waiter's competence and rationality. The narrative operationalises class as a vehicle for racism. The 'pathos of inequality' (Nederveen Pieterse 1992) between race and class emerges strongly in the use of the 'beanie' as a marker of otherness. These associations reveal the mutual reinforcement and interwovenness of race and class. Neatness and cleanliness are properties that the white and bourgeois claim as inherent to its race and class position and, therefore, what sets it apart from the black, working-class, unemployed position. Therefore, in the co-constructive dualism conjured in the narrative quoted above, racialising and classing others in social interactions serves as reiteration of white (bourgeois) supremacy in a particular space. Through micro-injustices blended into familiar practices (Essed 2002:207-208), white selves and white spaces are produced.

The other effect is the regulation of black bodies in white spaces. The 'beanie' as not only a mark of otherness, but a claiming of otherness can also be understood using Hage's (2000) theorisation that the other 'exhibits too much will' independently from the white nationalist and thus threatens the dominance required by white nationalism to make its space 'homely' (p. 70). In the above excerpt, the 'beanie' therefore signifies an unruly black body. Hage's analysis applies to the Australian national context, but is also apposite for the Afrikaner neo-nationalist localisation of Afrikaans whiteness in South Africa. Disciplining the wearer of the 'beanie' through the 'clown' and 'incompetence' attributions thus aids a white self-constitution as rational, effective, and 'all-powerful nationalist' in the fantasy space of the 'homely nation' (p. 70). Reaffirming the other as 'object of exclusion', white nationalists can imagine themselves masters of a territory (Hage 2000:48).

The next excerpt references Centurion in an operationalisation of culture to sidestep explicit racism:
Pieta (35): 'In Centurion everybody ... is quite respectable ... They will really never use a crude [racist] word, never mind a swear word ... [But] they assume you are semi-racist ... They say they aren't ... [My husband's] brother is an engineer ... He'll say 'we are doing a project again with the Groenewalds [Afrikaans surname], so it is taking long.

Researcher: Meaning?

Pieta: That is the black people. Green [stands] for Groenewald ...'

The respondent confirms that racism has been stigmatised but then describes new racist encoding. In this cultural twist, an Afrikaans surname cloaks a reference to black people: the Afrikaans word groen in the surname Groenewald means green. A word play is set in motion in which 'the Groenewalds' invokes green as stand-in for every skin colour except white. This construction hinges on an understanding of race as a property that belongs to black people, as opposed to the understanding of white people as race-less because they are the unmarked normative standard of humanness. The use of the term 'Groenewald' puts skin colour in the foreground as the most salient characteristic. The black other is rendered even more alien through the use of a colour that does not occur in human skin. White superiority is confirmed through its implicit differentiation from a hidden blackness (greenness) rendered equivalent with 'slowness' in time, wit, and competence.

The next text confirms that ethnicity and culture are thin veils masking the entrenchment of a micro-apartheid, using methods of ethnic cleansing to whiten Afrikaans space. Again, race trumps ethnicity. Speaking Afrikaans does not qualify subjects for inclusion because race remains pivotal, if hidden. When prompted about the inclusion of coloured people who speak Afrikaans, Ansie claims 'shock' at a racist action undertaken in her white suburb:

Ansie (57): 'A very prominent brown [an Afrikaans postapartheid term for coloured] family got a nasty letter ... that they don't belong here ... The chairperson of the residents' association ... said ... the [male head of the coloured family] felt really very shocked and offended by the whole tenor of the letter ... Everybody is shocked and disappointed because they are really nice people and he holds a high position. [Their presence] is to the benefit of our community. It was really bad for us because a guy doesn't know where it is coming from [it is an anonymous letter] because then you could act accordingly ... [You] feel disempowered [and] shocked to say there are people among you that hold these kinds of views'.

In a performance of anti-racism, the subject denies a shared white stance by repeatedly wielding 'shock' that people exist 'among us with such ideas'. This denial is contradicted by the ostensible 'inability' to take action, with the anonymity of the attack as excuse. There is no suggestion of lodging the attack with the law enforcement agencies, despite South Africa's 1996 Constitution and new legislation providing a basis for such action. Ignorance emerges as strategic white disposition, as per Mills' (1997:18) description of 'an inverted epistemology, an epistemology of ignorance, a particular pattern of localised and global cognitive dysfunctions (which 
are psychologically and socially functional), producing the ironic outcome that whites will in general be unable to understand the world they themselves have made'. Allowing a coloured family into their suburb - that is, embracing the racial other - would call the whiteness of Ansie and her neighbours into question. Neither Afrikaansness nor class ('he holds a high position') qualify the coloured family for access to whiteness.

The next excerpt shows the entrenchment of whiteness through a persistent refraining from questioning racial divisions and its conditions. Ignorance is iteratively installed as white buffer, even as the white subject confesses to being haunted by its black other.

Ansie: [My] family and friends in Johannesburg ... at work level there is greater [racial] mixing but I'm not sure people necessarily socialise together afterwards.

Researcher: Do you discuss why it is like that?

Ansie: No actually not. We just go on with our lives ... If anybody thought about it they would not have a problem in principle to have black friends ... I wish I knew where the thing lies ... It is a massively upsetting realisation that we don't have black or brown people that we can invite over. It is something that haunts me.

'There are still contexts that get stuck', in the words of respondent Katrien. This observation captures the analysis in this section, in that Afrikaner nationalism's grand design of projecting the Afrikaner identity onto a nation state has been replaced with much reduced spaces made homely with micro-apartheid. The town, Orania, in the rural province of the Northern Cape, attracts notable attention as an attempt to create an exclusive white Afrikaans space. Less noticeable are the white Afrikaans enclaves created by stealth in geographically specific suburban sites in South Africa's urban centres. This phenomenon is here identified as a form of neo-nationalism, here called Afrikaner enclave nationalism, a South African version of Hall's concept of the defensive 'return to the local'. Postcolonial tumult is stemmed with identity anchors that steady 'Afrikaners' in ethno-racial spaces not unlike the laagers used by their Dutch ancestors. Laagers were ox wagons drawn in defensive formations during the inland advance of Dutch colonial settlement into South Africa in the nineteenth century. In the twenty-first century, new forms of migration take place. Although many white Afrikaans speakers emigrate to the US or Europe, or to former colonies such as Australia and Canada, those that remain undertake what is here called inward migration, also in search of white dominions. The apartheid principles of volkseie (exclusive to the volk) and eie sake (own affairs) (Norval 1996) are reactivated and directed at smaller territories to create micro-apartheid geographies. 'Natural' apartheid divisions are, in lieu of state enforcement, privatised.

Facilitating the entrenchment of these exclusive geographies is symbolic articulation to create virtual white spaces in a plethora of cultural products, using the Afrikaans language as vehicle, as the next section explores.

\section{Cultural escape route to a virtual white world: Sarie women's magazine}

Hall (1997b) reminds us that capitalism drives west-centric global mass culture to 'invade' and 'weave' particularist forms into its expansion (p. 29), with consumption as pleasure. Thus 'an ethnicised group of individual consumercitizens [is] constructed through the twin operations of defensive ethnicity and neoliberalism with their shared utility of facilitating retreat from public spaces' (Blaser \& van der Westhuizen 2012:387). The Afrikaner enclave nationalists gather under the sign of consumption. This neo-nationalism hinges on the basic precept of capitalism private property - and is enabled by the wholesale privatisation and monetisation of life under neoliberalism (Brown 2005). Individuals become Afrikaners by becoming consumers of Afrikaner space and culture. Afrikaner identity is enacted through consumption. As was the case with Afrikaner nationalism (Hofmeyr 1987), die taal (the language) is central. White Afrikaans subjects beat their retreat into their white Afrikaans world through the plethora of Afrikaans-language cultural products spawned by reinvented neoliberal Afrikaner organisations, from the media to cultural industries to trade unions (Van der Westhuizen 2015). A wholesale neoliberalisation of Afrikaner identity occurs.

Sarie women's magazine has the second highest circulation of women's magazines in South Africa despite its small target market: white, Afrikaans, heterosexual women comparatively limited in a population of 52 million of which white people constitute only 4.5 million. The relative popularity and concomitant advertising load of the publication, owned by the formerly Afrikaner nationalist Nasionale Pers (National Press) company, serve as testimony to the enduring economic gravitas of its audience. This section draws on a discourse analysis of the magazine's 12 editions during its sixtieth anniversary year in 2009, which finds black people to be only rarely admitted onto Sarie's pages. Reading Sarie is to move in a virtual white world. This corresponds with Du Plessis's (2012) analysis that Nasionale Pers segments its target markets in accordance with apartheid boundaries.

In an implicit equivalence with blackness, Sarie texts produce Africa as 'unknowably other' (Chambers 1997:189-194). An undifferentiated 'Africa' is filled with its over-used colonial meaning of 'dark continent' or, alternatively, as the exotic other: 'lively' and 'colourful' (Sarie, Editor's Letter, January 2009). 'South Africa' is invoked with Afrikaans cultural imagery, such as Springbok rugby, or with nostalgia for a lost white, Afrikaans world. Sarie becomes a stand-in that offers a brief respite from the world 'out there', delivering a particular 'home' also outside South Africa:

When Sarie is delivered my heart beats $[\ldots]$ pure Afrikaans $[\ldots]$ We remember the home-things. Marlein Fanoy, Stanford (Britain), April 2009. 
... I am ... reading Sarie that my mom-in-law posted all the way from Graaff-Reinet ... With every word I read, I miss home and I think of the words 'We for you, South Africa'. I sing it softly while an excitement bubbles in me about the articles that follow. Thanks, Sarie, that you could let me feel so close to home in a foreign country. Jana Larson, Lourdes, August $2009^{3}$.

This letter invokes lines from the apartheid-era national anthem Die Stem (The Voice). Nostalgia is articulated with remnants of the apartheid discourse in repeated attempts to anchor this dislocated whiteness. Its dislodgment stems from South Africa's decentring as 'home' (Steyn 2003), most obviously for Afrikaans white emigrants scattered across the globe but also for those who remain behind. As Johanna van der Walt of Centurion ('Letter of the Month', July 2009) puts it: she needs a 'GPS for the heart' to 'give me just a little indication of what direction I should go to arrive home'. Sarie's sixtieth commemoration in 2009 created discursive opportunities for white nostalgia by stealth, as can be seen in the editions of that year. Afrikaner nationalist signifiers such as the 'founder' of South Africa, VOC employee Jan van Riebeeck, the Voortrekker Monument commemorating Dutch settlers and Die Stem are uncritically reaffirmed in Sarie as coordinates for inward migration.

Sarie's white space is gendered and sexualised. Inward migration is to class-based territories, where specific versions of sexuality, gender and race create an exclusive and excluding ethnic configuration, as the next section explores.

\section{Middle-class heteronormativity as bedrock of the white Afrikaans enclave}

The internal economy of differences in the Afrikaner neonationalist enclave is as highly hierarchical as its external division of differences, and reflects the external division in ways that draw on colonial intersectionalities. The institutions of commerce and religion serve as spaces to iterate and validate particularist practices of race, gender, sexuality, and class. Sometimes commerce and religion conflate to reproduce these practices and associated identity formations, as will be seen in the second example in this section.

The Sarie Editor's Letter of April 2009 amplifies the workings of power at the micro-level by using the discursive reach of the magazine to carry it beyond its immediate space of enactment. The text effects a particular ethno-racial gendering. It describes a scene in a small-town hair salon, depicting the salon as a space for social reproduction: a place 'to gather, to socialise and to be made pretty'. Comments are quoted by a man that the Editor's Letter designates oom ('uncle'), an Afrikaans form to indicate respect when addressing an older man, which remains in use in some locales. 'Oom Jan' delivered 'his wife' for a haircut at a salon, where the editor was also present. The Editor's Letter describes a performance of the male gaze, followed by masculine pronouncement on women's bodies: he 'checked out every woman' before 'thanking the hairdressers for helping keep SA's women so pretty' (emphasis in original). The editor concludes in a normalising manoeuvre: 'I told you hair is important. More than that, it is a case of national interest!' The editor 'playfully' recasts masculine appropriation and the policing of women as an acknowledgement of woman's role as 'national symbol'. Playfulness here serves to normalise rather than subvert because it does not problematise panoptical $^{4}$ masculinity (Bartky 1990). It circumscribes 'woman' in the patriarchal order of signification as body, object, spectacle, and symbol (De Lauretis 1987:20). Moreover, a rural hair salon with Sarie's white, upper-middle class editor as client would exclude many if not most of the local women on the basis of class and race, including through the racial coding of hair ${ }^{5}$. The column's unstated norm is of an invisibilised whiteness reminiscent of the National Party's 'White South Africa' (Van der Westhuizen 2007:128). 'Oom Jan' could only proclaim his appropriation of the space if it were a white, feminine, Afrikaans 'we' that 'gather, socialise and get pretty' there. Thus, a white space is produced and then claimed under the misnomer 'South African' spaces. This phantasmatic territorial claim (Rattansi 1994:33, 65) hinges on a particularist set of racialising and gendering norms. The phantasmatic aspect is emphasised by the use of the phrase 'South Africa', conjuring a past moment when Afrikaner nationalists laid claim to the whole of the country, 'their' nation state. The exclusion of black others is effected with white heteromasculinity's stamp of approval on white Afrikaans heterofemininity as 'the national standard', alongside an invisibilised middle classness. This reproduction installs a particular ethno-racial heteronormative gender hierarchy as requirement for its nostalgic micro re-enactment of apartheid to take place. Feminine self-improvement continues in the service of a privatised volk reproduced in white Afrikaans spaces, conjured and sanctioned by Sarie, which also serves as a virtual space of the same order.

This study finds Sarie's white Afrikaans mini-microcosm in the hair salon iterated in so-called 'cell groups', gendersegregated post-apartheid fundamentalist church groups that function as spaces of privatised ethno-whiteness predicated on consumerism and heteronormativity:

Pieta (35): It is a little ... show-off ... People who are in cell groups they invite ... the whole cell group with all their children... [to] children's parties that are so lavish you can't think that child is three years old ... They cost four five thousand rand ... [Everybody mentions] the new Audi they bought ... They're sending the wife ... to Paris for a little break and that is all they talk about ... The one girl got engaged and she was wearing this little ring. Immediately when you see you think 'oh

4.Foucault (1991:212) describes panopticism as a micropower that classifies, hierarchises validates, and invalidates.

5.In 2005, the SA Human Rights Commission's chairperson won an Equality Court case against a hair salon after hairdressers refused to cut his hair 'because it is different to that of whites' (www.iol.co.za, 30 March 2005). See also the case involving hairdresser Tanya Louw (www.rapport.co.za, 29 April 2012).

6.Seemingly in contrast, Sarie also hosts a monthly column by a gender-nonconforming Afrikaans in contrast, Sarie also hosts a monthly column by a gender-nonconforming West's (2009:108) analysis of lesbian columnist Marianne Thamm's role in Sarie's English-language counterpart Fair Lady that these sexual others play the jester, English-language counterpart Fair Lady that these sexual others play the jester,
traditionally 'a eunuch, or a "female male," castrated and thus sexually neutered and safe'. Nataniël is Sarie's safe homosexual. 
they're probably still making the ring'. [I congratulated her and her response was] immediately 'listen this is not my ring' but so nervous that you will think this little golden ring is her ring.

In an article proffering normative 'explanations' of Afrikaner identity, Gouws (1996:20-21) draws on neoliberal thinker Fukuyama to naturalise an 'intricate link' between 'the desire for material possessions' and Afrikaner 'cultural identity'. Accordingly, Gouws affirms as a function of material accumulation the restoration of the 'voice, cultural space and respect' of the masculine-identified Afrikaner subject (pp. 20-21). Gouws, therefore, approves of the neoliberal mode of consumption as self-actualisation but reworks it as a way of reconstituting the Afrikaner neo-nationalist collective. His rendition hides the ethno-racial heteronormative configuration in which this collective is historically embedded. The text above surfaces this configuration as manufactured through consumption. In the narrative, the 'Afrikaner man' is an invisibilised centre, peeking out as purchaser of 'the ring' and in the odd use of the plural 'they're sending the wife'. The restoration of 'the Afrikaner' happens through myriad transactions, local and global, involving the institution of matrimony and the family. Purchases generate identities at a particularist sexual-gender-class intersection. These purchases render the children and 'the wife' commodities demonstrating affluence and therefore white bourgeois (masculine) validity. According to Gilroy (2007), reinvented racism (or 'new racism') casts the family in a primary generative role. Stoler (2002:381) disagrees that this feature is new, as what has been posited as the 'new' prominence of the family in racist discourses was previously also a feature of colonial racisms. In the South African context, the inward migration of white Afrikaans ethnics is contingent on the family as a centrepiece of the white enclave as a destination. This again exposes inward migration as a neonationalist impulse innovating on the notion of the nation as family writ large. The recreation of the lost 'White South Africa' on micro scale in white Afrikaans enclaves hinges on the family as much as the Afrikaner nationalist object of the volk did. After all, the family legitimises social hierarchy woman to man, child to adult - 'within a putative organic unity of interests' and therefore sanctions exclusions and hierarchies (McClintock 1993:61, 64). The neo-nationalist innovation is to conspire with neoliberalism, in particular consumption, as a self-generative mode, to reinforce this ethno-racially specific sex-gender-class configuration.

\section{Afrikaner enclave nationalism}

In conclusion, in a global context of a generalised upheaval in identity, the destabilisation of identities after apartheid provokes pushback, in this case by the formerly hegemonic identity of apartheid, 'the Afrikaner'. Although Afrikaner nationalism's territorial claims to a nation-state were defeated, neo-nationalist remnants seek to reclaim a purchase on white Afrikaans identities, albeit in shrunken territories. Drawing on a global revamping and re-clothing of race as a category of social subjugation, the spatial strategy of the defensive 'turn to the local' in this neo-nationalism involves an inward migration to white spaces. Culture, ethnicity, and class are deployed as Trojan horses to continually whiten spaces and retain racial hierarchies. In an example of space being produced through interrelations ranging from the global (the neoliberal edict of consumption as self-creation) to the 'intimately tiny', the lynchpin holding these dynamics together is the heteronormative, middle-class family, with consumption the primary mode of the generation of its white comfort zones. Iterative efforts to command the family as a sexual-gender-class-race compound are re-doubled as its significance as the institutional basis for this neo-nationalism is amplified, after the loss of the white state. This neonationalism retains diminished territorial purchase in what is here called Afrikaner enclave nationalism: privatised microapartheid maintained through gender and sexual policing in sites ranging from homes, hair salons, and restaurants to whole suburbs. Virtual white spaces in the form of Afrikaans media products serve as extensions of these whitened locales elaborations of the phantasm of the other-less universe.

\section{Acknowledgements Competing interests}

The author declares that she has no financial or personal relationships that may have inappropriately influenced her in writing this article.

\section{References}

Adhikari, M., 2005, Not white enough, not black enough. Racial identity in the South African coloured community, Ohio University Press, Athens.

Balibar, E., 1991, 'Is there a neo-racism?', in E. Balibar \& I.M. Wallerstein (eds.), Race, nation and class. Ambiguous identities, pp. 17-28, Verso, London.

Bartky, S.L., 1990, Femininity and domination. Studies in the phenomenology of oppression, Routledge, New York.

Bekker, S., \& Leildé, A., 2006, 'Class, race and language in Cape Town and Johannesburg', in S. Bekker \& A. Leildé (eds.), Reflections on identity in four African cities, pp. 145-165, African Minds, Cape Town.

Bell, D., \& Valentine, G., 1995, 'The sexed self. Strategies of performance, sites of resistance', in S. Pile, \& N. Thrift (eds.), Mapping the subject. Geographies of cultural transformation, pp. 143-157, Routledge, New York.

Billig, M., 1995, Banal nationalism, Sage, London.

Blaser, T. \& van der Westhuizen, C., 2012, 'Introduction: The paradox of post- apartheid Afrikaner identity: Deployments of ethnicity and neo-liberalism', African Studies 71(3), 380-390. http://dx.doi.org/10.1080/00020184.2012.740882

Brown, W., 2005, Edgework: Critical essays on knowledge and politics, University Press, Princeton, NJ.

Carpentier, N., \& de Cleen, B., 2007, 'Bringing discourse theory into media studies. The applicability of discourse theoretical analysis (DTA) for the study of media
practises and discourses', Journal of Language and Politics 6(2), 265-293. http:// dx.doi.org/10.1075/jlp.6.2.08car

Chambers, R., 1997, 'The unexamined', in M. Hill (ed.), Whiteness. A critical reader, pp. 187-203, New York University Press, New York.

Chipkin, I., 2007, Do South Africans exist? Nationalism, democracy, and the identity of 'the people', Wits University Press, Johannesburg.

De Lauretis, T., 1987, Technologies of gender. Essays on theory, film and fiction, Indiana University Press, Bloomington, IN.

Du Plessis, A., 2012, 'Afrikaanse Musiek: Eiendoms (Beperk) - (Groot op Gelukkige Eiland)' [Afrikaans Music: Property (Limited) - (Big on Happy Island)], in Litnet, viewed 13 January 2012, from http://www.litnet.co.za/Article/afrikaanse-musiekeiendoms-beperk-groot-op-gelukkige-eiland

Du Toit, M., 2003, 'The domesticity of Afrikaner Nationalism: Volksmoeders and the ACVV, 1904-1929', Journal of Southern African Studies 29(1), 155-176. http:// dx.doi.org/10.1080/0305707032000060485

Dyer, R., 2005, 'The matter of whiteness', in P.S. Rothenberg (ed.), White privilege: Essential readings on the other side of racism, 2nd edn., pp. 9-14, Worth Publishers, New York.

Erasmus, Z., 2005, 'Race and identity in the nation', in J. Daniel, R. Southall \& J. Lutchman (eds.), State of the Nation. South Africa 2004-2005, pp. 9-33, HSRC Press, Cape Town. 
Essed, P., 1991, Understanding everyday racism: An interdisciplinary theory, Sage, Newbury Park, CA.

Essed, P., 2002, 'Everyday racism', in D.T. Goldberg \& J. Solomos (eds.), A companion to racial and ethnic studies, pp. 202-215, Blackwell, Cambridge, MA.

Foucault, M., 1991 'Panopticism', in P. Rabinow (ed.), The Foucault reader. An introduction to Foucault's thought, pp. 206-213, Penguin, London.

Geschiere, P., \& Meyer, B., 1998, 'Globalisation and identity: Dialectics of flow and closure. Introduction', Development and Change, 29(4), 601-615. http://dx.doi. org/10.1111/1467-7660.00092

Geschiere, P., \& Nyammnjoh, F., 2000, 'Capitalism and autochthony: The seesaw of mobility and belonging', Public Culture 12(2), 423-452. http://dx.doi. org/10.1215/08992363-12-2-423

Gilroy, P., 2007, There ain't no black in the Union Jack, Routledge, New York.

Goldberg, D.T., 1993, Racist culture: Philosophy and the politics of meaning, Blackwell, Cambridge, $M A$.

Goldberg, D.T., 2002, 'Racial states', in D.T. Goldberg \& J. Solomos (eds.), A companion to racial and ethnic studies, pp. 233-258, Blackwell, Cambridge, MA.

Goldberg, D.T. \& Solomos, J., 2002, 'General introduction', in D.T. Goldberg \& J. Solomos (eds.), A companion to racial and ethnic studies, pp. 1-11, Blackwell, Cambridge, MA.

Gouws, T., 1996, 'Postmodern identity: History, language and cultural difference or: The true colours of the Rainbow Nation', New Contree 40, 13-25.

Hage, G., 2000, White nation. Fantasies of White supremacy in a multicultural society, Routledge, New York.

Hall, S., 1996, 'Introduction: Who needs identity?', in S. Hall \& P. du Gay (eds.) Questions of cultural identity, pp. 1-17, Sage, London.

Hall, S., 1997a, 'The local and the global: Globalization and ethnicity', in A.D. King (ed.), Culture, globalisation and the world-system, pp. 19-39, University of Minnesota Press, Minneapolis, MN.

Hall, S., 1997b, 'Old and new identities, old and new ethnicities', in A.D. King (ed.) Culture, globalisation and the world-system, pp. 40-68, University of Minnesota Press, Minneapolis, MN.

Hall, S., 2001, 'Negotiating Caribbean identities', in G. Castle (ed.), Postcolonial discourses. An anthology, pp. 281-292, Blackwell Publishers, Oxford.

Harris, C.I., 1995, 'Whiteness as property', in K.M. Crenshaw, N. Gotanda, G. Peller \& K. Thomas (eds.), Critical race theory. The key writings that formed the movement pp. 276-291, The New Press, New York.

Hattam, V.C., 2001, 'Whiteness: Theorising race, eliding ethnicity', International Labo and Working-Class History 60, 61-68.

Hofmeyr, I., 1987, 'Building a nation from words: Afrikaans language, literature and ethnic identity, 1902-1924', in S. Marks \& S. Trapido (eds.), The politics of race, class and nationalism in 20th century South Africa, pp. 95-123, Longman, London.

Keating, M. \& McGarry, J., 2001. Minority nationalism and the changing internationa order, Oxford University Press, Oxford.

Kriel, M., 2006, 'Fools, philologists and philosophers: Afrikaans and the politics of cultura nationalism', Politikon 33(1), 45-70. http://dx.doi.org/10.1080/02589340600618081

Kriel, M., 2012, 'A new generation of Gustav prellers? The Fragmente/FAK/Vrye Afrikaan movement, 1998-2008', African Studies 71(3), 426-445. http://dx.doi.org/ 10.1080/00020184.2012.740885

Laclau, E., \& Mouffe, C., 1990, Hegemony and socialist strategy. Towards a radical democratic politics, Verso, London.

Massey, D., 2005, For space, Sage, London.

McCall, L., 2005, 'The complexity of intersectionality', Signs 30(3), 1771-1800. http:// dx.doi.org/10.1086/426800

McClintock, A., 1993, 'Family feuds: Gender, nationalism and the family', Feminist Review 44(Summer), 61-80. http://dx.doi.org/10.2307/1395196

McCrone, D., 1998, The sociology of nationalism. Tomorrow's ancestors, Routledge, London.
Mills, C., 1997, The racial contract, Cornell University Press, Ithaca, NY.

Nederveen Pieterse, J., 1992, White on Black. Images of Africa and Blacks in western popular culture, Yale University Press, New Haven, CT.

Norval, A., 1996, Deconstructing apartheid discourse, Verso, London.

Peterson, V.S., 2000, 'Sexing political identities/nationalism as heterosexism', in S. Ranchod-Nilsson \& M.A. Tétreault (eds.), Women, states, and nationalism. At home in the nation?, pp. 55-81, Routledge, New York.

Posel, D., 2001, 'Race as common sense: Racial classification in 20th century South Africa', African Studies Review 44(2), 87-113. http://dx.doi.org/10.2307/525576

Rattansi, A., 1994, 'Western racisms, ethnicities and identities', in A. Rattansi \& S. Westwood (eds.), Racism, modernity and identity. On the Western Front, pp. 15-86, Polity Press, Cambridge.

Rattansi, A. \& Westwood, S., 1994, 'Modern racisms, racialised identities', in A. Rattansi \& S. Westwood (eds.), Racism, modernity and identity. On the Western Front, pp. 1-12, Polity Press, Cambridge.

Roediger, D., 2002, 'Whiteness and ethnicity in the history of white ethnics in the US', in P. Essed \& D.T. Goldberg (eds.), Race critical theories. Text and context, pp. 325-343, Blackwell Publishing, Malden, MA.

Smith, A.D., 1998, Nationalism and modernism. A critical survey of recent theories of nations and nationalism, Routledge, New York.

Steyn, M., 2001, 'Whiteness just isn't what it used to be'. White identity in a changing South Africa, State University of New York Press, Albany, NY.

Steyn, M., 2003, 'White Talk: White South Africans and the strategic management of diasporic whiteness', PhD dissertation, University of Cape Town.

Steyn, M., 2004, 'Rehybridising the Creole: New South African Afrikaners', in N. Distiller \& M. Steyn (eds.), Under construction. 'Race' and identity in South Africa today, pp. 70-85, Heinemann, Sandton.

Stoler, A.L. (2002). 'Racial histories and their regimes of truth', in P. Essed \& D.T. Goldberg (eds.), Race critical theories. Text and context, pp. 369-391, Blackwell Publishing, Malden, MA.

Terreblanche, S., 2012, Lost in transformation, KMM Publishers, Sandton.

Van der Westhuizen, C., 2007, White power and the rise and fall of the National party, Zebra Press, Cape Town.

Van der Westhuizen, C., 2013, 'Identities at the intersection of race, gender, sexuality and class in a liberalizing, democratizing South Africa: The reconstitution of "the Afrikaner woman"', PhD dissertation, University of Cape Town.

Van der Westhuizen, C., 2015, 'White power today', paper presented at a Roundtable on Whiteness, Afrikaans, Afrikaners: Addressing post-apartheid legacies, privileges and burdens, Mapungubwe Institute for Strategic Reflection, Johannesburg, 5th November.

Van Wyk \& Sharp, J., 2016. 'The Heart of Whiteness? Ethnography of a Boer Afrikaner settlement in post-apartheid South Africa', a paper presented at a seminar, May, University of Pretoria.

Verwey, C. \& Quayle, M., 2012, 'Whiteness, racism and Afrikaner identity in postapartheid South Africa', African Affairs 111(445), 551-575. http://dx.doi. org/10.1093/afraf/ads056

Vestergaard, M., 2001, 'Who's got the map? The negotiation of Afrikaner identities in post-apartheid South Africa', Daedalus 130(1), 19-44.

Vincent, L., 1999, 'The power behind the scenes: The Afrikaner Nationalist Women's Parties, 1915 to 1931', South African Historical Journal 40(1), 51-73. http://dx.doi. org/10.1080/02582479908671348

Vincent, L., 2000, 'Bread and honour. White working class women and Afrikaner nationalism in the 1930s', Journal of Southern African Studies 25(1), 61-78. http:// nationalism in the 1930s', Journal of Sou
dx.doi.org/10.1080/030570700108388

West, M., 2009, White women writing white. Identity and representation in (post) apartheid literatures of South Africa, David Philip, Claremont, South Africa.

Yuval-Davis, N., 2011, 'The dark side of democracy: Autochthony and the radical right' in OpenDemocracy.net, viewed 26 July, from http://www.opendemocracy. net/5050/nira-yuval-davis/dark-side-of-democracy-autochthony-and-radical-right 